\title{
Factors Associated with Reproductive Age Couples' Selection of Sterilization in the Era of the National Health Insurance Program
}

\author{
Faktor - Faktor yang Berhubungan dengan Pemilihan Kontrasepsi Mantap pada \\ Pasangan Usia Subur pada Era Program Jaminan Kesehatan Nasional
}

\author{
Achmadi S Nugroho 1 , Azhari², Awan Nurtjahyo ${ }^{3}$, Theodorus ${ }^{4}$ \\ 1,2,3 Department of Obstetric and Gynecology \\ ${ }^{4}$ Research Unit of Health and Medicine \\ Faculty of Medicine Universitas Sriwijaya \\ Dr. Mohammad Hoesin Hospital, Palembang
}

\begin{abstract}
Objective : To assess factors associated with the selection of contraceptive sterilization in reproductive age couples in Dr. Mohammad Hoesin Palembang hospital in the era of National Health Insurance program.
\end{abstract}

Methods : This cross sectional study was conducted between January - December 2017. The study sample was reproductive age couples (RAC) who were married and came to P2 UGD, maternity room and midwifery ward of Dr. Mohammad Hoesin Palembang hospital and metour inclusion criteria. All study participants were given a questionnaire to assess factors that influence the selection of contraceptive methods in women. Data were analyzed using SPSS software version 17.

Results: We found a significant relationship between number of children ( $P R=3.988 ; p$-value $=0.016)$, knowledge level $(P R$ $=3.893 ; \mathrm{p}$-value $=0.024)$ and husband support $(P R=5.233$; $p$-value $=0.009$ ) with sterilization contraceptive selection. In addition, there were no significant correlation between age $(P R=2.311, p$-value $=0.210)$, education level $(P R=1.893$, $\mathrm{p}$-value $=0.331)$, woman attitude $(P R=1.567, \mathrm{p}$-value = $0.758)$, availability of contraception ( $(P R=1.969$, $p$-value $=0.342)$, officer attitude $(P R=1.088, p$-value $=0.000)$ and information given by officer $(P R=1.378 ; p$-value $=0.719)$ 1,$310 ; p$-value $=0.802$ ) with selection of sterilization. With logistic regression test, we found that husband support was the most important factor to selection of sterilization contraception $(P R=4.266$, $p$-value $=0.040)$ followed by knowledge $(P R=3.620, p$-value $=0.041)$.

Conclusions : Sterilization selection in reproductive age couples at Dr. Mohammad Hoesin Palembang Hospitalis influenced by female knowledge and husband support.

Keywords : reproductive age couple, sterilization, tubal ligation, vasectomy

\begin{abstract}
Abstrak
Tujuan : Mengetahui faktor-faktor yang mempengaruhi pemilihan metode kontrasepsi mantap pada Pasangan Usia Subur di RSUP Dr. Mohammad Hoesin Palembang pada era Program Jaminan Kesehatan Nasional.
\end{abstract}

Metode : Penelitian potong lintang ini dilakukan antara Januari - Desember 2017. Sampel penelitian adalah pasangan usia subur (PUS) yang sudah menikah yang dating ke P2 UGD, kamar bersalin, dan bangsal kebidanan RSUP Dr. Mohammad Hoesin Palembang dan memenuhi kriteria inklusi. Semua peserta penelitian diberikan kuisioner untuk melihat faktor-faktor yang mempengaruhi pemilihan metode kontrasepsi pada perempuan. Data dianalisis dengan menggunakan SPSS versi 17.

Hasil : Pada penelitian ini didapatkan hasil terdapat hubungan yang bermakna antara jumlah anak $(P R=3,988$; $p=0,016)$, tingkat pengetahuan $(P R=3,893 ; p=0,024)$ dan dukungan suami $(P R=5,233 ; p$-value $=0,009)$ dengan pemilihan kontrasepsi mantap. Selain itu, didapatkan hasil terdapat hubungan yang tidak bermakna antara usia (PR $=2,311 ; p$-value $=0,210)$, tingkat pendidikan $(P R=1,893$; $p$-value $=0,331)$, sikap ibu $(P R=1,567 ; p$-value $=0,758)$, ketersediaan alat kontrasepsi $(P R=1,378 ; p$-value $=0,719)$, ketersediaan SDM $(P R=1,769 ; p$-value $=0,552)$, alur rujukan $(P R=1,976 ; p$-value $=0,342)$, sikap petugas $(P R=$ $1,088 ; p$-value $=1,000)$ dan informasi petugas $(P R=1,310$; $p$-value $=0,802$ ) dengan pemilihan kontrasepsi mantap. Dengan uji Regresi Logistik didapatkan hasil dukungan suami merupakan faktor yang paling berperan terhadap pemilihan kontrasepsi mantap $(P R=4,266$, $p$-value $=0,040)$ diikuti oleh pengetahuan $(P R=3,620, p$-value $=0,041)$.

Kesimpulan : Dukungan suami dan pengetahuan ibu merupakan faktor yang mempengaruhi pemilihan kontrasepsi mantap pada pasangan usia subur di Rumah Sakit Dr. Mohammad Hoesin Palembang.

Kata kunci : Kontrasepsi mantap, MOP,MOW, pasangan usia subur 


\section{INTRODUCTION}

Population problem currently faced by Indonesia is high population growth rate. The expected population growth rate was $1.1 \%$ in 2014 , but in fact rate of population growth rose by $0.4 \%$ from $1.45 \%$ (population census of 2000 ) to $1.49 \%$ (population census of 2010). High population growth rate will affect level of life and welfare of the population.

Projected number of reproductive age couples throughout Indonesia in 2012 reached 48.2 million. Only $61.9 \%$ of them use contraception. $57.9 \%$ using modern contraception and $4.0 \%$ using traditional contraception. Distribution of modern contraceptive methods in Indonesia is intrauterine device (IUD) $3.9 \%$, tubal ligation $3.2 \%$, vasectomy $0.2 \%$, subdermal implant $3.3 \%$, condom $1.8 \%$, injection $31.9 \%$, and pills $13.6 \%$. Percentage of traditional contraceptivemethod in Indonesia is abstinence 1.3\%, intercourse 2.3\%, and other methods $0.4 \% .{ }^{1}$ Factors associated with low coverage of national family planning program are lack of contraceptives supply, lack of human resources and poorcontraceptive counseling quality, besides that government policy in each region is not equal. ${ }^{2,3}$

Many factors influence the selection of contraceptive methods. Lawrence Green analyzes human behavior from health level. These behaviors are defined or formed from three factors: predisposing factors embodied in characteristics, knowledge, attitudes, beliefs, values, etc; enabling factors, embodied in social environment, availability or unavailability of facilities or health facilities; and reinforcing factors embodied in support of the nearest person, supportive attitudes and behavior of health workers in providing health education.

Based on those facts, we are interested in examining factors associated with the selection of contraceptive sterilization in reproductive age couples in Dr. Mohammad Hoesin Palembang Hospital in the era of the National Health Insurance Program.

\section{METHODS}

This cross sectional study was conducted between January - December 2017. Study sample was reproductive age couples (RAC) in the age of 15 - 49 years old that were married and came to P2 UGD, maternity room and midwifery ward of Dr. Mohammad Hoesin Palembang hospital and met our inclusion criteria. Data was collected using a questionnaire. Research questionnaire contained questions about maternal characteristics (age, belief, number of children, education level), level of knowledge, woman's attitude toward contraceptive methods, availability of contraceptives, availability of human resources, referral flow, and information of family planning given by officers. Data were analyzed using SPSS software version 17.

\section{RESULTS}

During the study period, we included 106 women of reproductive age who met our inclusion and exclusion criteria. General characteristics of study subjects are shown in table 1.

Table 1. General Characteristics of Study Subjects

\begin{tabular}{lcccc}
\hline Characteristics & \multicolumn{2}{c}{ Groups } & P-value \\
\hline & Sterilization & Non Sterilization & Total \\
Age (years), mean \pm SD & $31.44 \pm 6.61$ & $29.89 \pm 7.15$ & $30.15 \pm 7.06$ & $0.396^{\mathrm{a}}$ \\
Age, $\mathbf{n}$ (\%) & & & & $0.210^{\mathrm{b}}$ \\
$\leq 35$ & $11(61.1)$ & $69(78.4)$ & $80(75.5)$ \\
$>35$ & $7(38.9)$ & $19(21.6)$ & $26(24.5)$ \\
Residency, $\mathbf{n}(\%)$ & & & \\
Downtown & $6(33.3)$ & $52(59.1)$ & $58(54.7)$ & $0.082^{\mathrm{b}}$ \\
Suburban & $12(66.7)$ & $36(40.9)$ & $48(45.3)$
\end{tabular}




\begin{tabular}{|c|c|c|c|c|}
\hline Education level, n(\%) & & & & $0.353^{c}$ \\
\hline Uneducated & $0(0)$ & $1(1.1)$ & $1(0.9)$ & \\
\hline Elementary school & $5(27.8)$ & $22(25.1)$ & $27(25.5)$ & \\
\hline Junior high school & $5(27.8)$ & $12(13.6)$ & $17(16.0)$ & \\
\hline Senior high school & $5(27.8)$ & $41(46.6)$ & $46(43.4)$ & \\
\hline University & $3(16.6)$ & $12(13,6)$ & $15(14.2)$ & \\
\hline Employment, n(\%) & & & & $0.158^{c}$ \\
\hline Housewives & $13(72.1)$ & $75(85.2)$ & $88(83.0)$ & \\
\hline Doctor & $1(5.6)$ & $0(0)$ & $1(0.9)$ & \\
\hline Teacher & $1(5.6)$ & $1(1.1)$ & $2(1.9)$ & \\
\hline Private employee & $2(11.1)$ & $7(8.0)$ & $9(8.6)$ & \\
\hline Civil servant & $0(0)$ & $3(3.4)$ & $3(2.8)$ & \\
\hline Farmer & $1(5.6)$ & $1(1.1)$ & $2(1.9)$ & \\
\hline Business & $0(0)$ & $1(1.1)$ & $1(0.9)$ & \\
\hline \multicolumn{5}{|c|}{ Number of children, $\mathbf{n}(\%)$} \\
\hline$>2$ & $10(55.6)$ & $21(23.9)$ & $31(29.2)$ & $0.016^{b}$ \\
\hline$\leq 2$ & $8(44.4)$ & $67(76.1)$ & $75(70.8)$ & \\
\hline Total & 18 & 88 & 106 & \\
\hline
\end{tabular}

${ }^{\mathrm{a} I n d e p e n d e n t ~} T$ Test, $\mathrm{p}=0.05,{ }^{\mathrm{b}}$ Chi Square test, $\mathrm{p}$-value $=0.05,{ }^{\mathrm{c}}$ Pearson Chi-Square, $\mathrm{p}$-value $=0.05$

In chi square analysis we found a significant relationship between the number of children with the utilization of sterilization ( $p$-value $=0.016)$. Couples with more than two children were 3,988 times more likely to choose sterilization. We did not find any relationship between age and education level with the utilization of sterilization $(p>0.05)$ (Table 2).

There was a significant correlation between knowledge level and selection of sterilization (Table 2). Respondents with good knowledge level were 3.89 times more likely to choose sterilization compared to respondents with poor knowledge level $(P R=3.893 ; p$-value $=0.024)$. There was also a significant relationship between husband supports with sterilization choice. Woman with supportive husbands 5.2 times more likely to choose sterilization $(P R=5.233 ; p$-value $=0.009$ ). There was no significant correlation between woman's attitude ( $p$-value $=0.758)$, availability of contraception supply ( $p$-value $=0.719)$, availability of human resources $(p$-value $=0.552)$, referral flow (0.342), officer's attitude ( $p$-value $=$ 1.000 ), and information given by officer $=0.802$ ) with selection of sterilization.

Table 2. Relationship between Knowledge, Attitude, Availability of Contraception and Human Resources, Referral Flow, officer's Attitude, and Information Given by Officer with Selection of Sterilization

\begin{tabular}{|c|c|c|c|c|c|}
\hline \multirow{2}{*}{ Characteristics } & \multicolumn{2}{|c|}{ Group } & \multirow{2}{*}{ Total } & \multirow{2}{*}{$\begin{array}{c}\text { PR* }^{*} \\
\text { (CI 95\%) }\end{array}$} & \multirow{2}{*}{$P$-value } \\
\hline & Sterilization & Non Sterilization & & & \\
\hline Age & & & & & 0.210 \\
\hline$>35$ & 7 & 19 & 26 & 2.311 & \\
\hline$\leq 35$ & 11 & 69 & 80 & $(0.789-6.772)$ & \\
\hline Number of children & & & & & 0.016 \\
\hline$>2$ & 10 & 21 & 31 & 3.988 & \\
\hline$\leq 2$ & 8 & 67 & 75 & $(1.394-11.408)$ & \\
\hline Education level & & & & & 0.331 \\
\hline High & 10 & 35 & 45 & 1,893 & \\
\hline Low & 8 & 53 & 61 & $(0.680-5.265)$ & \\
\hline Knowledge & & & & & 0.024 \\
\hline Good & 8 & 15 & 23 & 3.893 & \\
\hline Poor & 10 & 73 & 83 & $(1.318-11.500)$ & \\
\hline \multicolumn{6}{|l|}{ Attitude } \\
\hline Good & 15 & 67 & 82 & 1.567 & 0.758 \\
\hline Poor & 3 & 21 & 24 & $(0.413-5.943)$ & \\
\hline
\end{tabular}




\begin{tabular}{|c|c|c|c|c|c|}
\hline $\begin{array}{l}\text { Contraceptive supply } \\
\text { Equipped } \\
\text { Unequipped }\end{array}$ & $\begin{array}{l}9 \\
9\end{array}$ & $\begin{array}{l}37 \\
51\end{array}$ & $\begin{array}{l}46 \\
60\end{array}$ & $\begin{array}{c}1.378 \\
(0.499-3.808)\end{array}$ & 0.719 \\
\hline $\begin{array}{l}\text { SDM supply } \\
\text { Available } \\
\text { Unavailable }\end{array}$ & $\begin{array}{c}15 \\
3\end{array}$ & $\begin{array}{l}65 \\
23\end{array}$ & $\begin{array}{l}80 \\
26\end{array}$ & $\begin{array}{c}1.769 \\
(0.469-6.674\end{array}$ & 0.552 \\
\hline $\begin{array}{l}\text { Referral flow } \\
\text { Easy } \\
\text { Complicated }\end{array}$ & $\begin{array}{c}13 \\
5\end{array}$ & $\begin{array}{l}50 \\
38\end{array}$ & $\begin{array}{l}63 \\
43\end{array}$ & $\begin{array}{c}1.976 \\
(0.648-6.022)\end{array}$ & 0.342 \\
\hline $\begin{array}{l}\text { Officers attitude } \\
\text { Good } \\
\text { Not good }\end{array}$ & $\begin{array}{c}11 \\
7\end{array}$ & $\begin{array}{l}52 \\
36\end{array}$ & $\begin{array}{l}63 \\
43\end{array}$ & $\begin{array}{c}1.088 \\
(0.385-3.073)\end{array}$ & 1.000 \\
\hline $\begin{array}{l}\text { Officer Information } \\
\text { Good } \\
\text { Poor }\end{array}$ & $\begin{array}{c}11 \\
7\end{array}$ & $\begin{array}{l}48 \\
40\end{array}$ & $\begin{array}{l}59 \\
47\end{array}$ & $\begin{array}{c}1.310 \\
(0.465-3.692\end{array}$ & 0.802 \\
\hline $\begin{array}{l}\text { Husband support } \\
\text { Yes } \\
\text { No }\end{array}$ & $\begin{array}{c}15 \\
3\end{array}$ & $\begin{array}{l}48 \\
40\end{array}$ & $\begin{array}{l}58 \\
48\end{array}$ & $\begin{array}{c}5.233 \\
(1.444-19.357)\end{array}$ & 0.009 \\
\hline
\end{tabular}

*Fisher exact test, 95\% CI

From the logistic regression test we found that woman's knowledge and husband support significantly influence sterilization choice. Respondents with good knowledge 3.62 times more likely to choose sterilization ( $P R=3.620$; $\mathrm{p}$-value $=0.041$ ) while woman with supportive husbands 4.266 times more likely to choose sterilization $(P R=4.266 ; p$-value $=0.040)$. However, the number of children and age were not significantly associated with sterilization choice $(p>0.05)$.

Table 3. Factors Associated with Sterilization Choice

\begin{tabular}{lcccc}
\hline Variables & \multicolumn{2}{c}{ Unadjusted* } & \multicolumn{2}{c}{ Adjusted** } \\
\hline & PR & P-value & PR & P-value \\
\hline Husband support & 5.233 & 0.009 & 4.266 & 0.040 \\
Knowledge & 3.893 & 0.024 & 3.620 & 0.041 \\
Number of children & 3.988 & 0.016 & 3.156 & 0.059 \\
Age & 2.311 & 0.210 & 2.318 & 0.203 \\
\hline
\end{tabular}

\section{DISCUSSION}

Female sterilization is a permanent female contraceptive method. Sterilization in women is done by binding or cutting or attaching a ring to both fallopian tubes that can be achieved by laparoscopy or minilaparotomy. Tubectomy or sterilization is a permanent and preferred way of contraception if women no longer wish for pregnancy. ${ }^{4,5}$

From 106 respondents in this study, only $34.9 \%$ used contraception. Sterilization is only selected by $17 \%$ of respondents. $65.1 \%$ of respondents refused to use contraception because they still wanted to have children, husband did not allow using contraception and pain/discomfort.

In this study subdermal implants were used by $16.7 \%$ of respondents, IUD by $44.4 \%$, sterilization by $33.3 \%$ and vasectomy by $5.6 \%$ of respondents. Results of this study were in accordance with data of contraceptive use in Dr. Moh. Hoesin Palembang Hospital in 2013. It was reported that implants were used by 71 acceptors (7.1\%), IUD by 687 acceptors (68.7\%) and tubal sterilization by 241 acceptors (24.1\%). While in 2014 implants were used by 25 acceptors (2.5\%), IUD by 627 acceptors $(62.7 \%)$ and tubal sterilization by 270 acceptors (27\%).

There are three main factors that influence behavior. First is the predisposing factor that becomes the basis of behavior. Predisposing factors include knowledge, attitudes, beliefs, traditions, perceptions, and socio-demographic statuses such as age, education, number of families, tribes and incomes. ${ }^{6}$ In this study there were no differences in age, age, residency, education and employment between groups.

We found a significant correlation between knowledge level and selection of sterilization. Respondents with good knowledge level were 3.89 times more likely to choose sterilization compared to respondents with poor knowledge level $(P R=3.893$; $p$-value $=0.024)$. This resultis in accordance results of Ismail and Sisca's study in 
Karangampel Kidul Village Indramayu. They found that respondents with good knowledge were 2.474 times more likely to choose sterilization. From our experience and study reports, we can conclude that behavior based on good knowledge will give a better resultsdue to high awareness, interest, and the existence of consideration and positive attitude. ${ }^{7,8}$

In this study we assessed availability of contraception and human resources, referall flow and information provided by officer as enabling factors. Based on statistical analysis, we did not found any significant relationship between availability of contraception ( $P R=1.378$; $p$-value $=0.719)$, and human resources $(P R=1,769$; $\mathrm{p}$-value $=0.552)$, referral flow $(P R=1.976$, $p$-value $=0.342)$, and information provided by officer $(P R=1.310 ; p$-value $=0.802)$ with sterilization selection.

Reinforcing factor is a factor that determines whether health measures receive support from close related person including health worker. 6 In this study we did not find any significant relationship between information provided by the officers ( $P R=1,310 ; p=0.802)$ with sterilization selection. However, there was a significant relationship between husband support $(P R=5.233, p$-value $=0.009)$ with sterilization selection.

Based on logistic regression tests, we found that the most contributing factor in contraceptive participation is the husband's support.Woman with supportive husbands was 4,266 times more likely to choose sterilization. Thus results were supported by Herlinawati et al (2012) that showed that there was a significant correlation between family support with sterilization participation in Pirngadi Hospital Medan (OR = 12.016; $\mathrm{p}$-value $=0.001){ }^{9}$

Husband's participation is a manifestation of the husband's responsibility in women's reproductive health. Husband will participate if he receives full information. It is known that limited information on family planning and reproductive health has resulted in lower men/husbands' participation. ${ }^{10,11}$

Inability to communicate in the decisionmaking process puts a woman in a relatively low bargaining position, so that their needs and wants are difficult to achieve. Women's decisions tend to be dominated by her husband's interests, even if it is related to the survival of women themselves such as reproductive health problems.

In this study the husband's support is the main determinant of sterilization. $83.3 \%$ of women who chose sterilization received husband support; itwas 2 times higherthan women who did not choose sterilization (48.9\%).

\section{CONCLUSION}

Sterilization selection in reproductive age couples at Dr. Mohammad Hoesin Palembang Hospital is influenced by female knowledge and husband support.

\section{SUGGESTION}

Acceptors husband needs to receive counseling about the benefits of female sterilization, and further research on the factors that affect the husband's support against sterilization is needed to reveal its effect on women sterilization selection.

\section{REFERENCES}

1. Hartanto H. Keluarga berencana dan kontrasepsi. Jakarta :Swadaya. 1996

2. BKKBN, BPS, Kementerian Kesehatan, USAID. Survei demografi dan kesehatan Indonesia 2012. Jakarta, 2013:1-8

3. Kementerian Kesehatan Republik Indonesia. Rencana aksi nasional pelayanan keluarga berencana 2014-2015. Jakarta, 2013:1-38.

4. Sulistyawati A. Pelayanan keluarga berencana. Jakarta : Salemba Medika. 2014:10-5

5. Proverawati $A$, Islaely $A D$, Aspuah A. Panduan memilih kontrasepsi. Yogyakarta, Nuhamedika, 2010:1-4.

6. Notoadmojo S. Ilmu perilaku kesehatan. Jakarta : Rineka Cipta.2010:1-21

7. Ismail, Sisca F. Hubungan tingkat pendidikan dan pengetahuan pasangan usia subur (PUS) terhadap pemilihan alat kontrasepsi mantap (kontap) di desa Karang Ampel Kidul kabupaten Indramayu. 2004:1:1-5

8. Azwar S. Sikap manusia teori dan pengukurannya, Ed 2.Yogyakarta : Pustaka Pelajar.1995:5-51

9. Herlinawati, Maya F, Heru S. Faktor-faktor yang berhubungan dengan pemakaian kontrasepsi tubektomi pada perempuan pasangan usia subur di RSUD Dr. Pringadi Medan. Fakultas Kesehatan Masyarakat Universitas Sumatera Utara.2012 
Indones J

10. Lawrence RE. Factors influencing physicians advice about female sterilization in USA: a national survey. Hum Reprod, 2011: 106-11
11. Nasution SL. Faktor-faktor yang mempengaruhi penggunaan MKJP di enam wilayah Indonesia. Jakarta : Puslitbang KB dan Keluarga Sejahtera BKKBN. 2011:31-5 